\title{
Detecting peatland drains with Object Based Image Analysis and Geoeye-1 imagery
}

\author{
J. Connolly ${ }^{1 *}$ and N. M. Holden²
}

\begin{abstract}
Background: Peatlands play an important role in the global carbon cycle. They provide important ecosystem services including carbon sequestration and storage. Drainage disturbs peatland ecosystem services. Mapping drains is difficult and expensive and their spatial extent is, in many cases, unknown. An object based image analysis (OBIA) was performed on a very high resolution satellite image (Geoeye-1) to extract information about drain location and extent on a blanket peatland in Ireland. Two accuracy assessment methods: Error matrix and the completeness, correctness and quality (CCQ) were used to assess the extracted data across the peatland and at several sub sites. The cost of the OBIA method was compared with manual digitisation and field survey. The drain maps were also used to assess the costs relating to blocking drains vs. a business-as-usual scenario and estimating the impact of each on carbon fluxes at the study site.

Results: The OBIA method performed well at almost all sites. Almost $500 \mathrm{~km}$ of drains were detected within the peatland. In the error matrix method, overall accuracy (OA) of detecting the drains was $94 \%$ and the kappa statistic was 0.66 . The OA for all sub-areas, except one, was $95-97 \%$. The CCQ was $85 \%, 85 \%$ and $71 \%$ respectively. The OBIA method was the most cost effective way to map peatland drains and was at least $55 \%$ cheaper than either field survey or manual digitisation, respectively. The extracted drain maps were used constrain the study area $\mathrm{CO}_{2}$ flux which was 19\% smaller than the prescribed Peatland Code value for drained peatlands.

Conclusions: The OBIA method used in this study showed that it is possible to accurately extract maps of fine scale peatland drains over large areas in a cost effective manner. The development of methods to map the spatial extent of drains is important as they play a critical role in peatland carbon dynamics. The objective of this study was to extract data on the spatial extent of drains on a blanket bog in the west of Ireland. The results show that information on drain extent and location can be extracted from high resolution imagery and mapped with a high degree of accuracy. Under Article 3.4 of the Kyoto Protocol Annex 1 parties can account for greenhouse gas emission by sources and removals by sinks resulting from "wetlands drainage and rewetting". The ability to map the spatial extent, density and location of peatlands drains means that Annex 1 parties can develop strategies for drain blocking to aid reduction of $\mathrm{CO}_{2}$ emissions, $\mathrm{DOC}$ runoff and water discoloration. This paper highlights some uncertainty around using one-sizefits-all emission factors for GHG in drained peatlands and re-wetting scenarios. However, the OBIA method is robust and accurate and could be used to assess the extent of drains in peatlands across the globe aiding the refinement of peatland carbon dynamics .
\end{abstract}

Keywords: Remote sensing, Peatlands, Drain detection, Carbon dynamics, Satellite imagery, GIS/Object based image analysis, Cost effective, Ecosystem services

\footnotetext{
*Correspondence: john.b.connolly@dcu.ie

1 School of History and Geography, Dublin City University, St. Patrick's

Campus, Drumcondra, Dublin 9, Ireland

Full list of author information is available at the end of the article
} 


\section{Background}

Peatlands represent about $2-3 \%$ of the global terrestrial environment and store about $25 \%$ of global soil organic carbon (SOC) stock [1], estimated to be 547 Gt [2]. On an a per-area basis, peatlands store more carbon than any other terrestrial ecosystem [3], but this carbon stock is vulnerable to ecosystem disturbance [4-8]. Disturbance can be natural or anthropogenic [9] and includes drainage to enable the development of agriculture, forestry, peat extraction (for fuel or horticulture) or for road construction $[8,10,11]$. Drainage is the first step in the anthropogenic modification of peatlands [12-15]. Peatlands in both the southern and northern hemispheres have been drained [12, 14, 16], and between 1990 and 2008, global $\mathrm{CO}_{2}$ emissions from drained peatland increased by about 20\% from 1058 to 1298 Mton [17]. The drainage and conversion of about $308,500 \mathrm{~km}^{2}$ or $52 \%$ of Europe's temperate bogs for peat mining and agriculture over the last century has turned them from a moderate sink to a source of greenhouse gases [18, 19].

Much research has focused on the hydrological and physical effects of drainage on peatland ecosystems, but in recent years, there has been a concerted effort to understand the effects of drainage and subsequent drain blocking on ecosystem functions and dissolved organic carbon (DOC) dynamics, particulate organic carbon (POC) dynamics and net C flux [11, 16, 20-25]. Open cut drains increase drainage density and lower the water table of peatlands [22]. They can also lead to drying, shrinkage and subsidence in the surrounding peat. In Wales, the cutting of drains into upland blanket bog led to the creation of localised dry zones within $2 \mathrm{~m}$ of the drains, a reduction in surface water and a lowering of the water table within $5 \mathrm{~m}$ of the drains [25]. Such modifications change the balance between aerobic and anaerobic conditions in the peatland, exposing anaerobic zones to oxygen and increased oxidisation [24]. Peatland drains are greenhouse gas hotspots [26, 27], they also act as conduits allowing DOC and POC to be released into the natural drainage network, discolouring drinking water supplies and contributing to $C$ emissions $[22,26$, 28-30]. The SOC stock of peatlands is stable only so long as water-logged anaerobic conditions are maintained [31, 32]. Therefore drainage can lead to mobilisation of carbon via $\mathrm{CO}_{2}$, DOC and POC as well as increasing the risk of deeper peat drying and becoming more vulnerable to fire events [8].

With new understandings of peatlands and their importance as stores of carbon $(\mathrm{C})$, earlier attempts to drain peatlands are now regarded as being a threat to the preservation of the ecosystem and its $C$ security [30, 33]. Given the potential impact that drains have on peatland ecosystem services there is a need to identify drained networks for conservation assessment [34]. However, determining the extent, location and density of drainage systems is often a difficult and expensive task [22]. Peatland drains have been surveyed in several upland blanket peat catchments in northern Britain [22] and have been mapped using ground surveys and aerial photography interpretation [20, 35]. Airborne thermal imagery and LiDAR have been used to measure near surface hydrology but these data underestimated the volume and depth of surface drainage networks [33]. Field surveys produce accurate datasets however, they involve high labour costs $[34,36]$. Therefore, the task of determining the extent, location and density of drainage systems is often difficult and expensive [22].

The extent of peatland drains can clearly be seen on high resolution imagery [37], therefore image analysis methods to extract these data could be used to create drain maps. Remote sensing can be used to map and monitor peatlands over very wide areas [38] using both spectral-oriented data $[39,40]$ and object-oriented data [41]. Low and medium resolution multispectral imagery have been used to map the extent of peatlands. Pflugmacher et al. [40] examined the potential of using the moderate resolution imaging spectroradiometer (MODIS) low resolution imagery to map peatlands over large areas. Medium resolution satellite imagery has also been used to map peatlands on the Isle of Skye in Scotland [42]. MODIS (250 $\mathrm{m}$ resolution) was also used to examine peatland disturbance in the Wicklow Mountains [43]. However, while low and medium resolution satellite images are useful for broad scale mapping of peatland extent and condition over large areas [44], only high resolution imagery is suitable for mapping sub-metre sized linear features such as drains.

Object based image analysis (OBIA) software can be trained to extract the spatial extent of specific objects or features from medium and high resolution images using machine learning techniques with user-defined spectral, spatial, temporal and ancillary information [35, 45]. Peatlands in Quebec, Canada, were classified using an object-oriented approach with SPOT-4 imagery [46]. An object-oriented classification was used with medium resolution India Remote Sensing (IRS) imagery to identify disturbance on raised bogs in Ireland [44]. A semi-automatic object based approach was used to map the extent of peatlands in James Bay, Quebec, Canada very high resolution QuickBird imagery [47]. Evrendilek et al. [38] used Geoeye-1 imagery to quantify changes in a peatland between 1944 and 2009, although they had difficulty separating water bodies and ditches.

Peatland drains are linear features that are both small (i.e. less than $2 \mathrm{~m}$ wide) and spatially extensive [48]. OBIA is a useful tool for extracting fine scale features 
from high resolution imagery [44]. Extracted data can be used to refine estimates of the impact of anthropogenic disturbance on peatlands and their carbon stocks. There is a lack of information on the development of techniques to extract fine scale drain data from peatlands. However, OBIA has been used to extract fine scale linear features such as roads, power line tracks and informal walking trails. Narrow linear disturbance features have been detected in forests used both very high resolution (VHR) QuickBird and medium resolution SPOT imagery [49] and object-based image analysis has been used to extract roads from a variety of backgrounds [50].

The objective of this work was to extract information on the extent of man-made drains in a peatland area using OBIA and high resolution imagery. As drains impact on the carbon dynamics and ecosystem function of peatlands, this technique could be a cost-effective way to identify and map the spatial extent of peatland drains over large area to refine land use and management plans.

\section{Methods}

The study area was located within a low-level Atlantic blanket bog complex in the West of Ireland [51] $\left(54^{\circ} 7^{\prime} 41^{\prime \prime} \mathrm{N}, 9^{\circ} 48^{\prime} 44^{\prime \prime} \mathrm{W}\right)$ (Fig. 1). The area of this peatland is ca. 11,750 ha and it is located close to sea level (from sea level to $\sim 70 \mathrm{~m}$ asl). The mean (1961-1990) annual precipitation at the nearby Belmullet weather station was $1142 \mathrm{~mm}$ [52]. Peat depth is estimated to range from 0.04 to $0.58 \mathrm{~m}$ [53]. Peat depth observations from the nearby Glenamoy bog-complex indicated this range is realistic [54]. An area of about 1700 ha [55] was drained in the late 1950s (David Fallon, Personal Communication) and cutaway to provide fuel for the nearby de-commissioned Bellacorrick peat-fired power station [13]. Much of this industrial peatland area was exhausted (referred to as cutaway) and taken out of production [56]. Several other areas comprising of $\sim 1203$ ha of Atlantic blanket bog had small surface drains (called ditches) installed. The peat at these sites was not extracted but the drains were not blocked. Intact blanket bog in the area has been designated EU Priority Habitat status under the Habitats directive 92/43/EEC [56].

A geo- and ortho- rectified multi-spectral image (Geoeye-1) was acquired for the study area on the 26th August 2010 GMT. The image covered $68 \mathrm{~km}^{2}$. Geoeye- 1 has four spectral bands: blue $(450-510 \mathrm{~nm})$; green $(510-580 \mathrm{~nm})$; red $(655-690 \mathrm{~nm})$; near infra-red $(780-920 \mathrm{~nm})$. These spectral bands have a spatial resolution of $1.84 \mathrm{~m}$ [57]. The image also has a higher resolution panchromatic band $(0.46 \mathrm{~m})$ with a spectral range from $450-800 \mathrm{~nm}$. In the image there is $7 \%$ cloud cover and the local solar azimuth angle was $164.97^{\circ}$ and the local solar zenith angle was $45.46^{\circ}$. The multispectral image was pan-sharpened to
$0.5 \mathrm{~m}$ using the Brovey transform method in ArcGIS to create the very high-resolution image [58] which was used to aid identification of the extent of peatland drains. Within the area of interest the drains were straight and about $1 \mathrm{~m}$ wide. They are located at intervals of $15 \mathrm{~m}$. However, there were some instances where the side walls of drains have collapsed or they have infilled with vegetation.

The first step for the OBIA was to delineate the extent of peatland in the image (Geoeye-1) using the Derived Irish Peat Map Version 2 (DIPMv2) [51]. It was assumed that all areas falling inside the DIPMv2 delineated area were peat. Urban areas, lakes, agricultural land, clouds and shadows were all masked. A training dataset was created by digitising selected linear drains in the image. Most of the drains that were digitised are intact and therefore easy to see in the image. However, some drains have collapsed or have are overgrown with vegetation. These drains were also digitised. In the digitisation process a line was drawn along the centre of each drain. This helps to ensure that spectral contamination from edge pixels was minimised. Digitised segment lengths ranged from 0.34 to $434 \mathrm{~m}$ with an average length of $100 \mathrm{~m}$. The resulting training dataset consists of 700 digitised lines extending to $70,263 \mathrm{~m}$.

These training data were used to train the OBIA software [Feature Analyst (FA)] to identify and extract peatland drains. In FA, the OBIA algorithms are proprietary and the training is implemented in a black box. However, FA uses spatial context information, meaning that some parameters can be adjusted by the user at the start of the extraction process [59]. Here, several FA spatial parameters were selected and adjusted including: Feature Selector-Small Manmade Feature which was set at $<5 \mathrm{~m}$; Input Representation-the Bull's Eye 1 option with Pattern Width 11 was selected; Masking included limiting the OBIA to the study area (type 1) as well as including both a cloud and shadow mask. The output options that were selected included output to vector and the aggregation of a minimum area of $0.25 \mathrm{~m}^{2}$ [59]. The output from the FA process is a vector file of linear features depicting an extensive network of drainage ditches. Closer examination revealed many errors in the drains extraction vector file. Landscape features including small steep slopes, shadow and streams were included. A key feature of FA is the iterative correction function. This allows for manual inspection of the output features and identification of both correct and incorrect features. Once this advanced training is complete the software can be re-run, refining the results. This iterative process removed erroneous classifications enabling the development of more accurate maps of the peatlands drains.

The traditional method for assessing the accuracy of maps is to use an error matrix (EM) [60]. The EM enables 


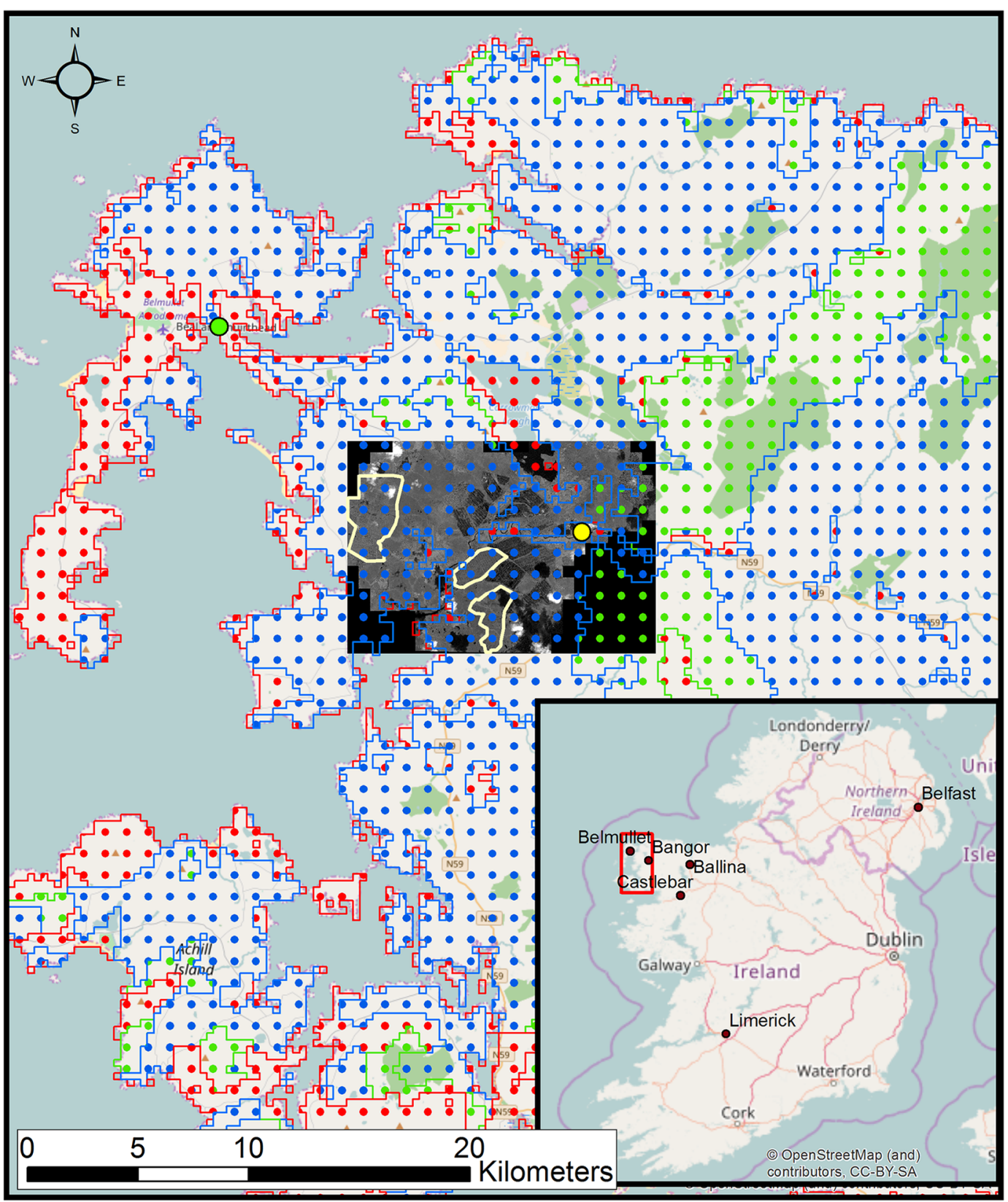

\section{Legend}

\section{$\ldots$ Not Peat -. Atlantic Blanket Bog $\bigcirc$ Belmullet \\ Reference Areas}

Fig. 1 Location of the study area, Co. Mayo, Ireland

the assessment of four variables: (1) true positives (drains in the image and on the ground); (2) true negatives (not drains in the image and on the ground); (3) false positives (not drains on the ground but drains in the image); and
(4) false negatives (drains on the ground but not drains in the image). These data can then be used to calculate the user's accuracy (UA); producer's accuracy (PA); overall accuracy (OA) [60] and kappa statistic (KS) [61]. Given 
that the EM method is usually applied to assessing area it was decided to use a second assessment method which had been designed for assessing linear features such as roads i.e. the completeness, correctness and quality (CCQ) method [62].

Within the study area, five sub areas were delineated as reference areas i.e. reference area North (RAN); reference area North Central (RANC); reference area West (RAW); reference area Central (RAC) and reference area South (RAS) (Fig. 2). The first step in the EM method is to buffer the output map linear features to $1.5 \mathrm{~m}$. This buffer gives each line an area which represents the width of the drains on the ground. Hawth's tools [63] (an extension for ArcGIS) was used to create and randomly distribute 3000 data points across all five reference areas. In addition, 500 independent data points were created and randomly distributed within each reference area. This dual approach allowed the assessment of accuracy across the entire area as well as assessment within each reference area. Points that fall within the buffered areas were classified as a drain; those outside the buffered areas were classified as not-drains.

There were some issues with the EM method: the buffered drains cover a very small percentage area of the entire area. Most of the random points fell outside these buffered areas, in the not-drain areas. The reference data was therefore biased towards these areas. While the EM results depict a relatively good accuracy, the authors felt it was necessary to use an accuracy assessment method that specifically examines the linear features themselves.

The CCQ has been used to assess the accuracy of extracted data related to roads [62]. However, CCQ requires a comprehensive validation dataset. This was created by manually digitising all drains within each reference area resulting in reference dataset extending to $76,635 \mathrm{~m}$ (minimum and maximum segment lengths of 0.35-435 m). In the CCQ method, the output vector file is compared to this high-quality validation dataset. The accuracy of how well the extracted dataset relates to the reference dataset $[62,64]$ is examined. Completeness refers to the percentage of the reference network that is successfully extracted by the detection algorithm, correctness is the percentage of extracted network matched by the reference network and quality is the contribution of the matched roads to the entire extracted and reference network [64]. Higher percentage values indicate more accurate results.

The cost effectiveness of using OBIA versus manual digitisation and field survey was also examined. The main variables included were labour, data, software costs and equipment needed for the field survey. The labour costs associated with both the manual digitisation (MD) and
OBIA methods are similar i.e. labour $=€ 17 / \mathrm{h}$ (according to the Irish University Association (IUA) rates for a research assistant); imagery and software coasts (€2000). However, some ground truthing is essential for the OBIA method and requires a surveyor and field assistant $(€ 44$, $€ 14 / \mathrm{h}$ respectively) as well as factoring in mileage, car hire and accommodation costs. The costs associated with the field survey include health and safety in the field i.e. it is necessary to have two people working together in the field thus labour is more expensive i.e. $€ 44 / \mathrm{h}$ (William Hamilton, Personal Communication) for an experienced surveyor and $€ 14 / \mathrm{h}$ (IUA rates) for a field assistant. There are also various field survey equipment and costs including high accuracy GPS, travel and accommodation (€3520).

The effect of the drains on the carbon dioxide $\left(\mathrm{CO}_{2}\right)$, Methane $\left(\mathrm{CH}_{4}\right)$ and DOC fluxes at the study site was calculated for six scenarios using different emission factors from several studies in the Ireland, the UK and from the IPCC (Table 1). The two intact blanket bog scenarios are included as controls. The Fluxes for intact blanket bog A are calculated using figures from Koehler et al. [65] for a blanket bog in south-west Ireland. While intact blanket bog B uses IPCC Tier 1 figures for $\mathrm{CO}_{2}$ and $\mathrm{CH}_{4}$ and the Koehler et al. figure [65] for DOC. There are two drained scenarios: the Drained/BAU (DBAU) scenario uses emission factors from Reed et al. [66] and Evans et al. [26], while the Mapped Drains/BAU (MDBAU) scenario uses the drain area extracted in this study with figures for $\mathrm{CO}_{2}$ from Wilson et al. $[67,68]$ (Table 2). Two re-wetting scenarios are included used IPCC $[69,70]$ and local figures $[65,71]$ for the various fluxes and used to examine the different between BAU and re-wetting.

In the mapped drain scenario, the peatland was divided into zones based on the Wilson et al. [11] observations that drains lead to localised dry zones within $2 \mathrm{~m}$ of drains, and a reduction in surface water and a lowering of the water table within $5 \mathrm{~m}$ of the drains [25]. This information was used to segregate the peatland into several zones. The drain polygons extracted in the OBIA method are about $1.4 \mathrm{~m}$ wide. The area of these drain polygons was calculated using the OBIA extracted drains (see Table 2). They were buffered using tools in ArcGIS 10.2, to represent the dryer zones identified by Wilson et al. [11]. These zones included: (1) localised dry zones (the drain area was buffered to $2 \mathrm{~m}$ in ArcGIS); (2) lower water table zones (the localised dry zone areas were buffered to $3 \mathrm{~m}$ ) and (3) the remaining peat located outside these buffered zones was, in most cases, about $3 \mathrm{~m}$ wide. Each zone was assigned an emission value (Table 2) and it was assumed zone 3 had a similar value to zone 2 as the high drainage density prohibited wetter areas there. 


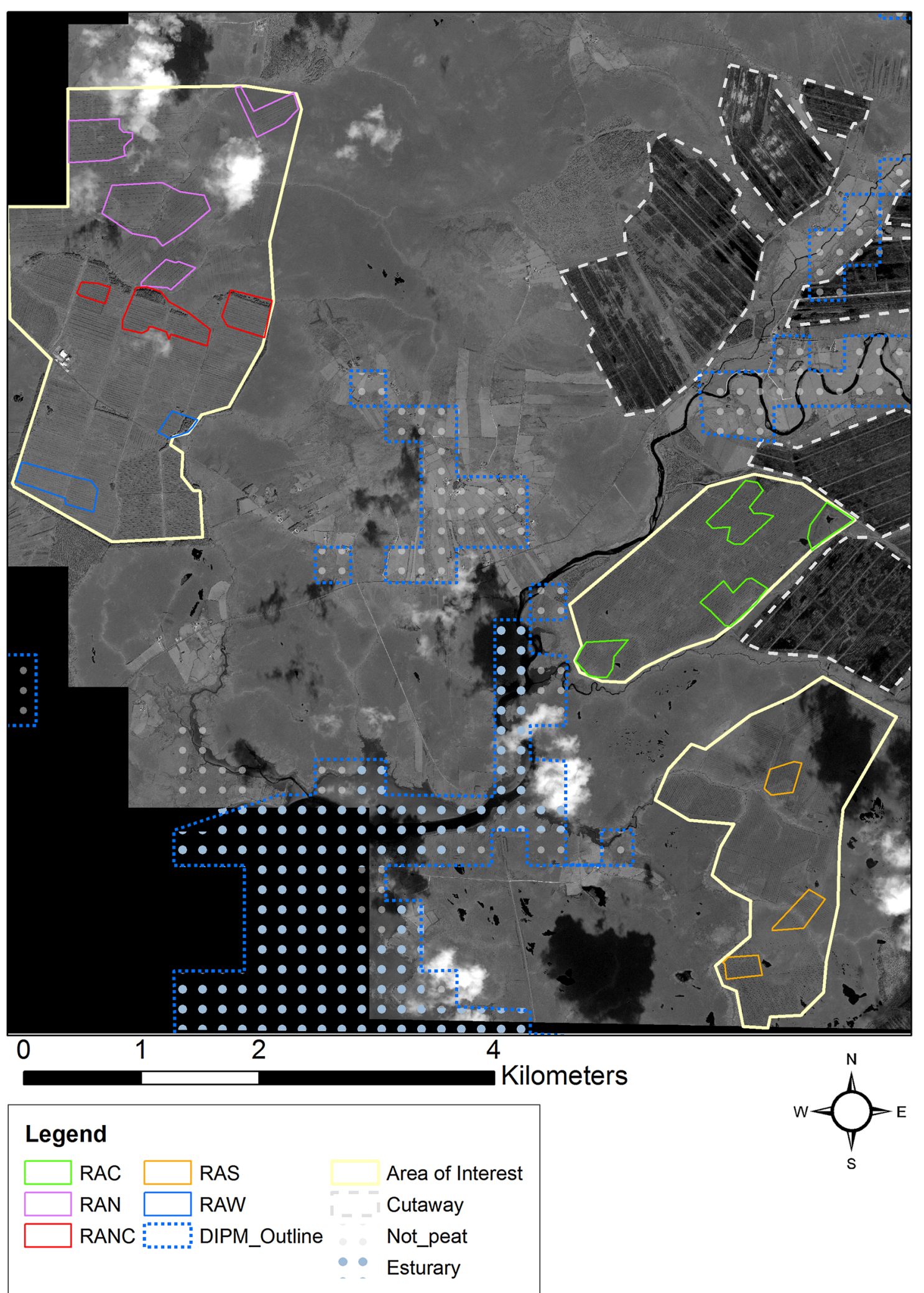

Fig. 2 The reference areas within the study site 
Table 1 Emission Factors for six scenarios $\left(\mathrm{t}^{\mathrm{CO}_{2}}\right.$ eq. $\mathrm{ha}^{-1}$ year $\left.^{-1}\right)$ and study area fluxes (t $\mathrm{CO}_{2}$ eq.) with estimated costs of re-wetting vs business as usual

\begin{tabular}{|c|c|c|c|c|c|c|}
\hline & Intact Blanket bog $A^{c}$ & Intact Blanket bogB ${ }^{d}$ & $\mathrm{DBAU}^{\mathrm{a}, \mathrm{e}}$ & MDBAU ${ }^{b, f}$ & Re-wet $A^{g}$ & Re-wetB ${ }^{h}$ \\
\hline $\mathrm{CO}_{2}$ & -0.48 & -2.12 & 1.40 & 1.14 & 0.04 & -1.04 \\
\hline $\mathrm{CH}_{4}$ & 0.04 & 1.73 & 2.00 & 2.00 & 1.73 & 0.09 \\
\hline DOC & 0.14 & 0.14 & 1.00 & 1.00 & 0.14 & 0.14 \\
\hline Emission factor & -0.30 & -0.25 & 4.40 & 4.14 & 1.91 & -0.81 \\
\hline Study area (t $\mathrm{CO}_{2}$ eq.) & -357 & -301 & 5294 & 4984 & 2298 & -975 \\
\hline \multicolumn{7}{|l|}{ EU ETS rate: $€ 5.48^{i}$} \\
\hline Drain blocking & $€ 0$ & $€ 0$ & $€ 0$ & $€ 0$ & $€ 486,100$ & $€ 486,100$ \\
\hline Annual emission costs & $-€ 1,958^{k}$ & $-€ 1648$ & $€ 29,010$ & $€ 27,312$ & $€ 12,593$ & $-€ 5340$ \\
\hline Initial cost $(€)$ year 1 & $-€ 1958$ & $-€ 1648$ & $€ 29,010$ & $€ 27,312$ & $€ 498,693$ & $€ 480,759$ \\
\hline Total costs (year 30)' & $-€ 58,744$ & $-€ 49,448$ & $€ 870,288$ & $€ 819,356$ & $€ 863,884$ & $€ 325,888$ \\
\hline
\end{tabular}

a Drained/business as usual

b Mapped drains/ business as usual

c $\mathrm{CO}_{2}, \mathrm{CH}_{4}$ and DOC derived from Koehler et al. [65]

d $\mathrm{CO}_{2}$ derived from Bonn et al. [69] and $\mathrm{CH}_{4}$ IPCC Tier 1 [70] and DOC from Koehler et al. [65]

e $\mathrm{CO}_{2}$ and $\mathrm{CH}_{4}$ derived from Reed et al. [66] and DOC from Evans et al. [26]

f $\mathrm{CO}_{2}$ derived in this study using figures from Wilson et al. [67, 68], $\mathrm{CH}_{4}$ Reed et al. [66] and DOC Evans et al. [26]

$9 \mathrm{CO}_{2}$ and $\mathrm{CH}_{4}$ from Bonn et al. [69] and IPCC Tier 1. [70] and DOC from Koehler [65]

h $\mathrm{CO}_{2}$ and $\mathrm{CH}_{4}$ from Wilson et al. [71] and DOC from Koehler et al. [65]

i $€ 5.48$ per tonne $\mathrm{CO}_{2}$ (21/11/2016-https://carbon-pulse.com/category/eu-ets/)

j Includes the cost of OBIA (€4852) and cost of blocking drains $(€ 481,247)$ at $€ 400 / h^{*} 1203$ ha

${ }^{k}$ The minus value indicates the amount that is saved by not draining peatlands

I The total costs equals the initial year 1 cost plus the annual emission cost multiplied by 29

Table 2 Using drain extent extracted here to estimate $\mathrm{CO}_{2}$ emissions in the drains and adjacent zones

\begin{tabular}{lclc}
\hline & Area (ha) & $\begin{array}{l}\mathbf{t ~ C O}_{\mathbf{2}} \text { eq. } \\
\text { ha }^{-1} \text { year }^{-1}\end{array}$ & $\begin{array}{l}\text { Study site } \\
\mathbf{t ~ C O}_{\mathbf{2}} \text { eq. }\end{array}$ \\
\hline Drain $^{\mathrm{a}}$ & 68 & 0.53 & 36.16 \\
Drain $^{2} \mathrm{~m}^{\mathrm{b}}$ (zone 1) & 199 & 1.76 & 350.67 \\
Drain $2 \mathrm{~m}+3 \mathrm{~m}^{\mathrm{b}}$ (zone 2) & 239 & 1.14 & 272.36 \\
Drain $5 \mathrm{~m}+1.5 \mathrm{~m}^{\mathrm{b}}$ (zone 3) & 697 & 1.14 & 794.28 \\
Average site emissions & & 1.14 & \\
Total & 1203 & & 1453.47 \\
\hline
\end{tabular}

${ }^{a}$ Wilson et al. [67]

${ }^{b}$ Wilson et al. [68]

Estimated costs and potential savings were calculated for the scenarios using the EU Emissions Trading Scheme (ETS) rates for $\mathrm{CO}_{2}$ [72]. The costs for both the intact and drained/BAU scenarios were based on the total study area flux multiplied by the EU-ETS rate on 21st November, 2016. The re-wetting scenarios included the cost of OBIA and drain blocking. Bord na Móna calculated that the average cost of blocking drains on a raised bog was $€ 400 /$ ha [73], although others in the UK have found that figure to be higher [74]. All values were calculated for a thirty-year period [66].

\section{Results}

Within the peatland complex 496,630 m of drains were identified (Fig. 3). The first iteration identified many nonman made features such as rivers, streams and shadows in forestry plantations. The second iteration of the OBIA process removed these features and on further analysis resulted in the most accurate drain maps. An initial visual analysis of the results indicated that the feature extraction process had performed well in extracting the extent of drains. This was supported by quantitative analysis (Table 3). The EM method reported the overall accuracy for the extracted drains across the entire reference area to be $94 \%$, the user's accuracy was $83 \%$ and the producer's accuracy was $60 \%$. These results indicate that from a map user's point of view the method worked well. This was supported by a kappa statistic of 0.66 which shows substantial agreement [61, 75] between the extracted data and the reference data. The CCQ also depicts a high accuracy of the OBIA method for detecting the drains in this area. Across the entire study area, the completeness $=85 \%$, correctness $=85 \%$ and quality $=71 \%$. This indicates that $85 \%$ of the reference dataset was identified by the extracted drain data, that $85 \%$ of the extracted drains were matched by the reference data and $71 \%$ of the matched drains contributed to the entire extraction and reference drain network. 


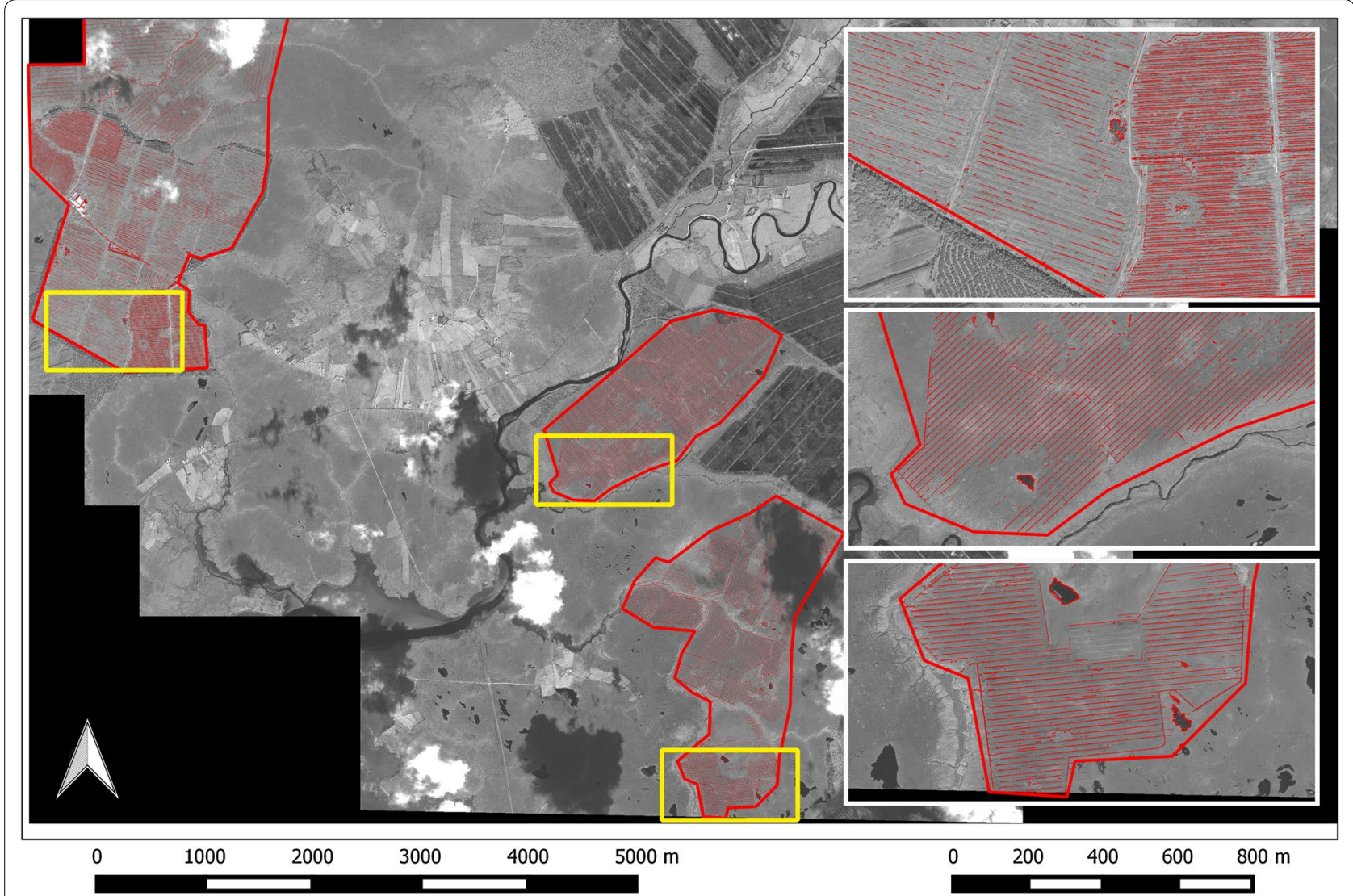

Fig. 3 Spatial extent of extracted drains within the study area

Table 3 The error matrix for accuracy assessment of the reference areas within the study area

\begin{tabular}{lcllll}
\hline Extracted peatland drains & & & \\
\hline $\begin{array}{l}\text { Linear validation } \\
\text { dataset }\end{array}$ & Drain & No drain & Total & $\begin{array}{l}\text { Producer } \\
\text { accuracy }\end{array}$ \\
\hline Drain & 193 & 131 & 324 & 0.60 \\
No drain & 39 & 2637 & 2676 & 0.99 \\
Total & 232 & 2768 & & 3000 & \\
User accuracy & 0.83 & 0.95 & & & \\
Kappa statistic & 0.66 & & OA & 0.94 \\
\hline
\end{tabular}

Within the five reference areas, the EM method showed that there was little variation in overall accuracy and producer's accuracy for not-drain, but some variation in the producer's accuracy, user's accuracy and Kappa Statistics for the drains. This variation was also reflected in the CCQ data (Table 4). The greater values for producer's accuracy and user's accuracy for not drained pixels indicate little misclassification but this seemed to be less reliable for the drain pixels. Of particular note is the producer's accuracy for the RAW which was $<50 \%$ indicating some misclassification. This low value is also seen in the CCQ assessment. The extraction method works well for detecting drainage in this peatland area located in the West of Ireland. It works particularly well for detecting drains that were clearly visible by eye in the high-resolution imagery. However, it was also reliable for detecting drains that have experience some level of change i.e. have collapsed or are overgrown.

In terms of cost effectiveness, the OBIA method was estimated to be the least expensive way of mapping peatland drains. It was considerably cheaper than manual digitisation and field survey, both of which are relatively labour intensive (Table 5) or require high additional costs (Equipment, travel, accommodation). The estimated cost for mapping the drains at this study site was $€ 4852$ (OBIA); $€ 10,690$ (field survey) and $€ 11,459$ (manual digitisation). The flux scenarios for this site ranged from $-357 \mathrm{t} \mathrm{CO}_{2}$ eq. to $5294 \mathrm{t} \mathrm{CO}_{2}$ eq. for the intact bog $\mathrm{A}$ and DBAU scenarios, respectively. The costs for each scenario can be seen in Table 1 . 
Table 4 Error matrices and CCQ results for overall and five sub reference areas

\begin{tabular}{|c|c|c|c|c|c|c|c|c|c|}
\hline \multirow[t]{2}{*}{ Name } & \multirow[t]{2}{*}{$\mathrm{OA}(\%)$} & \multicolumn{2}{|l|}{ PA } & \multicolumn{2}{|l|}{ UA } & \multirow[t]{2}{*}{ KS (\%) } & \multirow[t]{2}{*}{ Completeness (\%) } & \multirow[t]{2}{*}{ Correctness (\%) } & \multirow[t]{2}{*}{ Quality (\%) } \\
\hline & & D (\%) & ND (\%) & $\mathrm{D}(\%)$ & ND (\%) & & & & \\
\hline RAN & 95 & 61 & 99 & 88 & 96 & 70 & 81 & 93 & 75 \\
\hline RANC & 95 & 67 & 99 & 88 & 96 & 73 & 87 & 84 & 74 \\
\hline RAW & 93 & 43 & 100 & 92 & 93 & 92 & 74 & 81 & 59 \\
\hline RAC & 97 & 82 & 98 & 87 & 98 & 83 & 92 & 92 & 85 \\
\hline RAS & 95 & 74 & 97 & 77 & 97 & 73 & 86 & 83 & 73 \\
\hline $\mathrm{AOI}$ & 94 & 60 & 99 & 83 & 95 & 66 & 85 & 85 & 71 \\
\hline
\end{tabular}

$D$ drain, $N D$ not drain, $O A$ overall assessment, $P A$ producer's accuracy, $U A$ user's accuracy, $K S$ kappa statistic, $A O I$ area of interest i.e. total study site

Table 5 Comparison cost of each drain assessment method

\begin{tabular}{|c|c|c|c|c|}
\hline Methods & & Amount & Rate $(€)$ & Total cost $(€)$ \\
\hline \multirow{4}{*}{$\begin{array}{l}\text { Manual digitisa- } \\
\text { tion }\end{array}$} & Labour (hours) & 583 & $17^{\mathrm{a}}$ & 9951 \\
\hline & Imagery & 1 & 1256 & 1256 \\
\hline & $\begin{array}{l}\text { Software cost } \\
\text { (per day) }\end{array}$ & 97 & $2.6^{b}$ & 252 \\
\hline & Total & & & 11,459 \\
\hline \multirow[t]{10}{*}{ OBIA } & $\begin{array}{l}\text { Image analysis } \\
\text { labour (hours) }\end{array}$ & 120 & $17^{\mathrm{a}}$ & 2047 \\
\hline & Imagery & 1 & 1265 & 1265 \\
\hline & $\begin{array}{l}\text { Software cost } \\
\text { (per day) }\end{array}$ & 20 & $4.1^{c}$ & 82 \\
\hline & $\begin{array}{l}\text { Surveyor labour } \\
\text { (hours) }\end{array}$ & 16 & 44 & 700 \\
\hline & $\begin{array}{l}\text { Field assistant } \\
\text { labour (hours) }\end{array}$ & 16 & 14 & 224 \\
\hline & $\begin{array}{l}\text { Equipment (per } \\
\text { job) }\end{array}$ & - & - & 19 \\
\hline & $\begin{array}{l}\text { Lodgings and } \\
\text { subsistence }\end{array}$ & 1 & 125 & 125 \\
\hline & Mileage (km) & 576 & 0.59 & 340 \\
\hline & Car hire & 1 & $50^{d}$ & 50 \\
\hline & Total & & & 4852 \\
\hline \multirow[t]{7}{*}{ Field survey } & $\begin{array}{l}\text { Labour surveyor } \\
\text { (hours) }\end{array}$ & 124.2 & 44 & 5432 \\
\hline & $\begin{array}{l}\text { Labour field } \\
\text { assistant } \\
\text { (hours) }\end{array}$ & 124.2 & 14 & 1738 \\
\hline & $\begin{array}{l}\text { Equipment (per } \\
\text { job) }\end{array}$ & - & - & 144 \\
\hline & $\begin{array}{l}\text { Lodgings and } \\
\text { subsistence }\end{array}$ & 16 & 125 & 2000 \\
\hline & Mileage (km) & 1060 & 0.59 & 626 \\
\hline & Car hire & 1 & $750^{e}$ & 750 \\
\hline & Total & & & 10,690 \\
\hline
\end{tabular}

a $€ 17 / \mathrm{h}$ is calculated from the Irish Universities Association research pay scale for a research assistant on point 10 of the salary scale working

b, c Software cost per day (assuming a 3 year depreciation and the number of workdays as a ratio of 3 years of workdays as the proportion to cost to the calculation e.g. if used for 15 days, then $\left.[15 /(260 \times 3)]^{*} 2000\right]=$ cost of software)

d, e Car hire for 2 and 16 days, respectively

\section{Discussion}

According to both the EM and CCQ methods, the OBIA performs well detecting $\sim 500 \mathrm{~km}$ of drains across the study area. It was also the most cost effect way of mapping peatland drains in this intensively drained peatland area. In 2010, the condition of the drains ranged from intact to collapsed or overgrown. Intact drains were clearly visible while the collapsed/overgrown drains were not. Each sub-area was analysed individually to examine the effect of drain condition on accuracy. In the reference areas where the drains were in good condition (RAC, RAN, RAS and RANC) the OBIA method performed well (Table 4). The accurate extraction of drains was likely due to the high spectral contrast between dark peaty water in the drains and lighter vegetation on the surrounding peatland. However, as the drain condition deteriorates e.g. in the RAW area, vegetation invades the drains and the spectral contrast diminishes. This affects the ability of the OBIA method to detect these drains. The result of this could be seen in both the EM and CCQ accuracy assessment methods for RAW (Table 4). However, despite the reduced accuracy the method does extract the general structure and pattern of drains in the RAW area.

Map outputs need to be assessed for accuracy. Traditionally, when assessing the accuracy of a spatial area, an error matrix was used to assess user, producer and overall accuracy [60]. However there may be bias in its use in relation to the assessment of linear features [76]. Drains are usually represented as lines on a map. Linear features can be extensive over a spatial area, as in this case, they do not however have an area. The discretely sampled points used to populate an error matrix may be biased towards one land use because of the way it is represented on a map i.e. a drain (linear feature). In this case, the examination of accuracy involved a binary decision, either it is a drain or it is not a drain. Since the nondrain polygons cover much larger areas of land compared to the area covered by linear drain features, there was a strong bias towards non-drain polygons in the random 
point data. This can be seen in Table 4, where a very large number of random sample points (3000) were needed to ensure that the drains were adequately represented in the sample (324 or $~ 10 \%)$. This issue was somewhat alleviated by buffering the drains to give them an area (this area represents the drain on the ground more accurately than a line can). Despite the extraction method performing well in the EM method, it was felt that there was an optimistic bias in the data because about $90 \%$ of the sample points were restricted to homogenous non-drain areas [77]. Lathrop et al. [76] found that the EM accuracy assessment method, using discrete sample points, did not work well with linear object features because points are examined as coincident pixels rather than the objects [78]. Therefore, another method was needed to assess the accuracy of the OBIA method more reliably. The CCQ method overcame this optimistic bias. It measures how well the extracted data overlaps with a reference dataset. Overall, the CCQ method delivered a better assessment of the accuracy of the extracted data as it was assessed solely in relation to the high-quality reference dataset and there was no bias towards large homogenous areas i.e. non-drain.

This OBIA approach enabled a relatively rapid assessment of drain density at this site. Both MD and field survey are possible, however, MD was estimated to take over six times longer and was almost three time more expensive (Table 5). A field survey would take a similar amount of time to OBIA but was more than twice as expensive due to the safety requirement of having two people working in the field. While the OBIA method was not fully is automated, it did enable drain density to be accurately and cost effectively mapped over large areas. This OBIA method created accurate maps that record the spatial extent and drainage density of peatland drains. The condition of drains can also be inferred i.e. where the accuracy is lower and a drainage pattern is extracted it may indicate drains that are overgrown.

The method is robust and relatively easy to implement and could aid in the estimation of the impact of Land use, land use change and forestry in a cost-effective way. Emissions from Land Use Land Use Change and Forestry (LULUCF) are currently not accounted for in internal EU targets, they will, however be included in the EU's 2nd commitment period target in the Kyoto Protocol [79]. Since 2013, the Kyoto Protocol has allowed Annex 1 parties to account for greenhouse gas emission by sources and removals by sinks resulting from Wetlands Drainage and Rewetting (WDR) under Article 3.4. [80]. In the light of the Paris Agreement; EU targets for the 2nd commitment period and the Mapping and Assessment of Ecosystem Services (MAES) initiative [81] it is necessary to begin to refine spatial data related landscape carbon dynamics.

Wilson et al. [71] suggest that the one-size fits all approach may not be appropriate for different sites, particularly in relation to drain extent and its impact on the study area emissions. The main difference between the DBAU and MDBAU is related to the how the $\mathrm{CO}_{2}$ figure is calculated. The DBAU scenario is estimated on a tonnes of $\mathrm{CO}_{2}$ per hectare value derived from the Peatland Code [82]. While in MDBAU scenario, the area of drains and zones adjacent to drains is extracted using the OBIA method using flux measurements for each zone (Table 2). The emission factor for $\mathrm{CO}_{2}$ in the MDBAU scenario is about $19 \%$ lower that then the Peatland Code value. This difference equals to a $€ 50,000$ reduction in costs over the 30 -year period for this site of $1203 \mathrm{ha}$. When comparing both BAU scenarios with the re-wet scenarios, it is clear that the uncertainty between the IPCC Tier 1 and local emission factors have large implications with regard to the costs reduction. Analysis of these issues is beyond the scope of this paper, and it is difficult to come to a decisive conclusion without further clarification and refinement.

In this study, the OBIA method is successful in extracting maps of drainage extent and density from the Geoeye-1 high-resolution satellite image. Peatlands provide a number of ecosystem services including water purification and carbon storage [10, 83]. Drains impact on these services enhancing both emissions of $\mathrm{CO}_{2}$ and removal of DOC [30, 84]. This method could be used in tropical areas, though its use may be limited in areas where trees have overgrown and blocked the drain spectral signal. In several areas of the study site and particularly in the RAW area, the drains are overgrown and infilled; despite this the general structure of the drains was identified. The method could be applied in temperate and boreal zones where peatlands have been drained. The identification and mapping of drains over large areas is a cost-effective aid for the management of drain blocking campaigns. With the issues related to the impact of drains on peatlands, peatland ecosystems services and Article 3.4, it is essential that accurate maps of artificial peatland drain systems can be produced to identify: 1 . hotspots for $\mathrm{CO}_{2}$ emissions and DOC production and 2. suitable areas for drain blocking and rewetting.

Satellite remote sensing is a good tool for mapping peatland disturbance. While coarse spatial resolution imagery can be useful for mapping broad scale disturbance [43, 85], high resolution imagery is essential for mapping peatland drains $[44,68]$. The Copernicus satellites including Sentinal-1 and Sentinel-2 provide free images at high spatial $(10 \mathrm{~m})$ and temporal resolutions [86]. However, to detect small linear features, such as the industrial scale 
drainage featured in this study or drains create for domestic peat extraction, it is necessary to acquire very high spatial resolution images such as GeoEye-1 satellite data or images from aerial or UAV platforms $[18,44]$. The semiautomatic assessment methods used in this study can be used to extract valuable information useful to land managers and policy makers. OBIA offers a cost effective and accurate approach for extracting information on drainage extent and density from very high resolution satellite imagery. This semi-automatic method could be used to delineate and map drains and $\mathrm{CO}_{2}$ hotspots in large agricultural, peatland and wetland areas across the globe.

\section{Conclusions}

The OBIA method used in this study shows that it is possible to accurately extract fine scale features such as peatland drains over large areas, producing cost-effective maps. Globally, peatlands have been drained to support production of crops, fuel, livestock and timber [26]. Peatland drainage is extensive and increases aerobic decomposition and DOC export leading to a loss of ecosystem services such as sequestration and storage of $\mathrm{C}$ and the potential development of greenhouse gas hotspots $[8,26$, 27]. Despite the impact that drainage has on peatland carbon dynamics, there is a lack of methods for assessing the spatial extent and condition of peatland drains. Historically, this may be due to the difficulty and expense of surveying or mapping these small-scale features. However, as high resolution satellite data becomes increasingly available and software is developed to semi-automatically and automatically extract fine scale features, new insights into the carbon dynamics of natural ecosystems can be expected. The OBIA method explored here performed well for extracting data on the spatial extent and condition of peatland drains. The mapping of peatland drains is important in assessing how these extensive fine scale features may contribute to carbon dynamics in these sensitive ecosystems. This information is important for management, regulation and policy. The approach taken in this paper is robust and accurate. It could be applied to map the extent of drains aiding the monitoring of carbon dynamics in peatlands and wetlands across the globe.

\footnotetext{
Abbreviations

asl: above sea level; C: carbon; CCQ: completeness, correctness and quality; $\mathrm{CO}_{2}$ : carbon dioxide; DBAU: drained/business as usual; DIPMv2: derived Irish peat map version 2; DOC: dissolved organic carbon; EM: error matrix; EU: European Union; FA: feature analyst; Gt: gigaton; KS: kappa statistic; LULUCF: land use, land use change and forestry; MAES: mapping and assessment of ecosystem services; MDBAU: mapped drains/business as usual; MODIS: moderate resolution imaging spectroradiometer; Mton: megaton; OA: overall accuracy; OBIA: object based image analysis; PA: producer's accuracy; POC: particulate organic carbon; rac: reference area Central; RAN: reference area North; RANC: reference area North Central; RAS: reference area South; RAW: reference area West; SOC: soil organic carbon; UA: user's accuracy; VHR: very high resolution.
}

\section{Authors' contributions}

JC led the study including the analysis and assessment of the data and results and drafted the manuscript. NH provided extensive comments and contributed to the writing of the manuscript. All authors have given their consent for publication. Both authors read and approved the final manuscript.

\section{Author details}

${ }^{1}$ School of History and Geography, Dublin City University, St. Patrick's Campus, Drumcondra, Dublin 9, Ireland. ${ }^{2}$ UCD School of Biosystems and Food Engineering, University College Dublin, Belfield, Dublin 4, Ireland.

\section{Acknowledgements}

The authors are grateful for the support of the EPA STRIVE Programme which is funded by the Irish Government under the National Development Plan 2007-2013. The authors also wish to thank Dr. Rebekka Artz at The James Hutton Institute for an initial feasibility study to determine if peatland drain mapping was possible in Forsinard, Scotland. Thank you to Dr. David Wilson and Dr. Florence Renou-Wilson of Earthy Matters Environmental Consultants for clarifying some issues and to David Fallon at Bord na Móna, for supplying some historic information. Thank you also to the two anonymous Reviewers whose suggestions improved the manuscript.

\section{Competing interests}

The authors declare that they have no competing interests.

\section{Availability of data and materials}

Data will not be shared due to commercial licences.

\section{Funding}

This research was funded by the Environmental Protection Agency of Ireland through the EPA STRIVE Programme which is funded by the lrish Government under the National Development Plan 2007-2013 (Project Number: 2008-FSS-6-S5). The funding agency did not have a role in the collection, analysis, interpretation of data or in the writing of the article.

Received: 24 December 2016 Accepted: 28 February 2017

Published online: 09 March 2017

\section{References}

1. Yu ZC. Northern peatland carbon stocks and dynamics: a review. Biogeosciences. 2012;9:4071-85.

2. Yu Z, Loisel J, Brosseau DP, Beilman DW, Hunt SJ. Global peatland dynamics since the Last Glacial Maximum. Geophys Res Lett. 2010;37:L13402. doi:10.1029/2010gl043584.

3. Dise NB. Peatland response to global change. Science. 2009;326:810-1. doi:10.1126/science.1174268.

4. Barber KE. Peatlands as scientific archives of past biodiversity. Biodivers Conserv. 1993;2:474-89. doi:10.1007/bf00056743.

5. Bridgham SD, Pastor J, Updegraff K, Malterer TJ, Johnson K, Harth C, et al. Ecosystem control over temperature and energy flux in northern peatlands. Ecol Appl. 1999;9:1345-58. doi:10.1890/1051-0761(1999)009[1345:ECOTAE]2.0.CO;2.

6. Page S, Jauhiainen J, Hooijer A. Greenhouse gas flux from tropical peatlands: context and controls. In: EGU General Assembly Conference Abstracts, Vol. 12; 2010. p. 1564.

7. Robroek BJM, Smart RP, Holden J. Sensitivity of blanket peat vegetation and hydrochemistry to local disturbances. Sci Total Environ. 2010:408:5028-34.

8. Turetsky MR, Benscoter B, Page S, Rein G, van der Werf GR, Watts A. Global vulnerability of peatlands to fire and carbon loss. Nat Geosci. 2015;8:11-4. doi:10.1038/ngeo2325.

9. Connolly J, Holden NM. Classification of peatland disturbance. Land Degrad Dev. 2011;24:548-55. doi:10.1002/ldr.1149.

10. Parry LE, Holden J, Chapman PJ. Restoration of blanket peatlands. J Environ Manag. 2014;133:193-205. doi:10.1016/j.jenvman.2013.11.033.

11. Wilson L, Wilson J, Holden J, Johnstone I, Armstrong A, Morris M. Ditch blocking, water chemistry and organic carbon flux: evidence that blanket bog restoration reduces erosion and fluvial carbon loss. Sci Total Environ. 2011:409:2010-8. 
12. Chapman S, Buttler A, Francez A-J, Laggoun-Défarge F, Vasander H, Schloter $\mathrm{M}$, et al. Exploitation of northern peatlands and biodiversity maintenance: a conflict between economy and ecology. Front Ecol Environ. 2003;1:525-32.

13. Dwyer DJ. The peat bogs of the Irish Republic: a problem in land use. Geogr J. 1962;128:184-93.

14. Fargione J, Hill J, Tilman D, Polasky S, Hawthorne P. Land clearing and the biofuel carbon debt. Science. 2008;319:1235-8. doi:10.1126/ science. 1152747

15. Joosten H, Clarke D. Wise use of mire and peatlands_-background and principles including a framework for decision making. Totnes: International Mire Conservation Group and International Peat Society; 2002.

16. Holden J, Chapman PJ, Labadz JC. Artificial drainage of peatlands: hydrological and hydrochemical process and wetland restoration. Progress Phys Geogr. 2004;28:95-123. doi:10.1191/0309133304pp403ra.

17. Joosten $\mathrm{H}$. The global peatland $\mathrm{CO}_{2}$ picture peatland status and emissions in all countries of the world [Draft]. Greifswald: Greifswald University; 2009.

18. Knoth C, Klein B, Prinz T, Kleinebecker T. Unmanned aerial vehicles as innovative remote sensing platforms for high-resolution infrared imagery to support restoration monitoring in cut-over bogs. Appl Veg Sci. 2013;16:509-17. doi:10.1111/avsc.12024.

19. Christensen TR, Friborg T, Byrne KA, Chojnicki B, Drösler M, Freibauer A, et al. EU Peatlands: current carbon stocks and trace gas fluxes. Lund: Geosphere-Biosphere Centre, Lund University; 2004.

20. Armstrong A, Holden J, Kay P, Francis B, Foulger M, Gledhill S, et al. The impact of peatland drain-blocking on dissolved organic carbon loss and discolouration of water; results from a national survey. J Hydrol. 2010;381:112-20.

21. Armstrong A, Holden J, Kay P, Foulger M, Gledhill S, McDonald AT, et al. Drain-blocking techniques on blanket peat: a framework for best practice. J Environ Manag. 2009;90:3512-9.

22. Holden J, Gascoign M, Bosanko NR. Erosion and natural revegetation associated with surface land drains in upland peatlands. Earth Surface Process Landf. 2007;32:1547-57. doi:10.1002/esp.1476.

23. Ramchunder SJ, Brown LE, Holden J. Environmental effects of drainage, drain-blocking and prescribed vegetation burning in UK upland peatlands. Progress Phys Geogr. 2009;33:49-79. doi:10.1177/0309133309105245.

24. Strack M, Waddington JM, Bourbonniere RA, Buckton EL, Shaw K, Whittington $P$, et al. Effect of water table drawdown on peatland dissolved organic carbon export and dynamics. Hydrol Process. 2008;22:3373-85. doi:10.1002/hyp.6931.

25. Wilson L, Wilson J, Holden J, Johnstone I, Armstrong A, Morris M. Recovery of water tables in Welsh blanket bog after drain blocking: discharge rates, time scales and the influence of local conditions. J Hydrol. 2010;391:377-86

26. Evans CD, Renou-Wilson F, Strack M. The role of waterborne carbon in the greenhouse gas balance of drained and re-wetted peatlands. Aquat Sci 2015;78:573. doi:10.1007/s00027-015-0447-y.

27. McNamara NP, Plant T, Oakley S, Ward S, Wood C, Ostle N. Gully hotspot contribution to landscape methane $\left(\mathrm{CH}_{4}\right)$ and carbon dioxide $\left(\mathrm{CO}_{2}\right)$ fluxes in a northern peatland. Sci Total Environ. 2008;404:354-60. doi:10.1016/j.scitotenv.2008.03.015.

28. Evans MG, Warburton J. Peatland Geomorphology and Carbon Cycling. Geogr Compass. 2010;4:1513-31. doi:10.1111/j.1749-8198.2010.00378.x.

29. Gibson HS, Worrall F, Burt TP, Adamson JK. DOC budgets of drained peat catchments: implications for DOC production in peat soils. Hydrol Process. 2009:23:1901-11.

30. Wallage ZE, Holden J, McDonald AT. Drain blocking: an effective treatment for reducing dissolved organic carbon loss and water discolouration in a drained peatland. Sci Total Environ. 2006;367:811-21. doi:10.1016/j.scitotenv.2006.02.010.

31. Charman D. Peatlands and Environmental Change. Chichester: Wiley; 2002.

32. Davidson EA, Janssens IA. Temperature sensitivity of soil carbon decomposition and feedbacks to climate change. Nature. 2006;440:165-73.

33. Luscombe DJ, Anderson K, Gatis N, Wetherelt A, Grand-Clement E, Brazier RE. What does airborne LiDAR really measure in upland ecosystems? Ecohydrology. 2015;8:584-94. doi:10.1002/eco.1527.
34. Crowe SK, Evans MG, Allott TEH. Geomorphological controls on the re-vegetation of erosion gullies in blanket peat: implications for bog restoration. Mires Peat. 2008;3:1-14.

35. Mladinich C. An evaluation of object-oriented image analysis techniques to identify motorized vehicle effects in semi-arid to arid ecosystems of the American West. GI Sci Remote Sens. 2010;47:53-77.

36. Michez A, Piégay H, Jonathan L, Claessens H, Lejeune P. Mapping of riparian invasive species with supervised classification of Unmanned Aerial System (UAS) imagery. Int J Appl Earth Obs Geoinform. 2016;44:88-94. doi:10.1016/j.jag.2015.06.014.

37. Lindsay RA, Charman DJ, Everingham F, O'Reilly RM, Palmer MA, Rowell TA, Stroud DA. The flow country: The peatlands of Caithness and Sutherland. Nature Conservancy Council. Peterborough; 1988.

38. Evrendilek F, Berberoglu S, Karakaya N, Cilek A, Aslan G, Gungor K. Historical spatiotemporal analysis of land-use/land-cover changes and carbon budget in a temperate peatland (Turkey) using remotely sensed data. Appl Geogr. 2011;31:1166-72.

39. Anderson K, Bennie JJ, Milton EJ, Hughes PDM, Lindsay R, Meade R. Combining LiDAR and IKONOS data for eco-hydrological classification of an ombrotrophic peatland. J Environ Qual. 2009;39:260-73. doi:10.2134/ jeq2009.0093.

40. Pflugmacher D, Krankina ON, Cohen WB. Satellite-based peatland mapping: potential of the MODIS sensor. Global Planet Chang. 2007:56:248-57.

41. Phua M-H, Tsuyuki S, Lee JS, Sasakawa H. Detection of burned peat swamp forest in a heterogeneous tropical landscape: a case study of the Klias Peninsula, Sabah, Malaysia. Landsc Urban Plan. 2007;82:103-16.

42. Brown E, Aitkenhead M, Wright R, Aalders IH. Mapping and classification of peatland on the Isle of Lewis using Landsat ETM+. Scott Geogr J. 2007;123:173-92.

43. Connolly J, Holden NM, Seaquist JW, Ward SM. Detecting recent disturbance on Montane blanket bogs in the Wicklow Mountains, Ireland using the MODIS enhanced vegetation index. Int J Remote Sens. 2011;32:2377.

44. Connolly J, Holden NM. Object oriented classification of disturbance on raised bogs in the Irish Midlands using medium- and high-resolution satellite imagery. Irish Geogr. 2011;44:111-35. doi:10.1080/00750778.2011. 615558.

45. O'Brien MA. Feature extraction with the VLS feature analyst system. In: Proceedings of the ASPRS 2003 annual conference. Anchorage; 2003.

46. Grenier M, Labrecque S, Garneau M, Tremblay A. Object-based classification of a SPOT-4 image for mapping wetlands in the context of greenhouse gases emissions: the case of the Eastmain region, Quebec, Canada. Can J Remote Sens. 2008;34:S398-413.

47. Dissanska M, Bernier M, Payette S. Object-based classification of very high resolution panchromatic images for evaluating recent change in the structure of patterned peatlands. Can J Remote Sens. 2009;35:189-215. doi:10.5589/m09-002.

48. Renou F, Farrell EP. Reclaiming peatlands for forestry: the Irish experience. In: Madsen PA, editor. Restoration of boreal and temperate forests. Boca Raton: CRC Press; 2005. p. 541-57.

49. He Y, Franklin SE, Guo X, Stenhouse GB. Object-oriented classification of multi-resolution images for the extraction of narrow linear forest disturbance. Remote Sens Lett. 2011;2:147-55.

50. Jin H, Li Z, Feng Y. Enhancing digital road map with lane details extracted from large-scale stereo aerial imagery using object-oriented image analysis. 2009.

51. Connolly J, Holden NM. Mapping peat soils in Ireland: updating the derived Irish peat map. Irish Geogr. 2009;42:343-52.

52. Met_Eireann. Rainfall. http://www.met.ie/climate/rainfall.asp. 2011.

53. Holden NM, Connolly J. Estimating the carbon stock of a blanket peat region using a peat depth inference model. Catena. 2011;86:75-85.

54. NPWS. Glenamoy bog complex-site synopsis. Department of Arts, Heritage and the Gaeltacht; 2006.

55. Hammond RF. The Peatlands of Ireland. Soil Survey Bulletin No 351981.

56. Farrell CA, Doyle GJ. Rehabilitation of industrial cutaway Atlantic blanket bog in County Mayo, North-West Ireland. Wetl Ecol Manag. 2003;11:2135. doi:10.1023/a:1022097203946.

57. GeoEye-1. GeoEye-1 Satellite Images|Satellite Imaging Corp 2017. http:// www.satimagingcorp.com/gallery/geoeye-1/. Accessed 20 Feb 2017.

58. Gillespie AR, Kahle AB, Walker RE. Color enhancement of highly correlated images. II. Channel ratio and "chromaticity" 
transformation techniques. Remote Sens Environ. 1987;22:343-65. doi:10.1016/0034-4257(87)90088-5.

59. Opitz D, Blundell S. Object recognition and image segmentation: the Feature Analyst ${ }^{\circledR}$ approach. In: Blaschke T, Lang S, Hay GJ, editors. Objectbased image analysis. Berlin: Springer; 2008. p. 153-67.

60. Congalton RG. A review of assessing the accuracy of classifications of remotely sensed data. Remote Sens Environ. 1991;37:35-46.

61. Viera AJ, Garrett JM. Understanding interobserver agreement: the kappa statistic. Fam Med. 2005;37:360-3.

62. Guo X, Dean D, Denman S, Fookes C, Sridharan S. Evaluating automatic road detection across a large aerial imagery collection. Int Conf Digital Image Comput Tech Appl. 2011;2011:140-5. doi:10.1109/DICTA.2011.30.

63. Beyer HL. Hawth's analysis tools for ArcGIS 2004. http://www.spatialecology.com/htools.

64. Harvey WA. Performance evaluation for road extraction. Société Française de Photogrammétrie et Télédétection. 1999;1:79-87.

65. Koehler A-K, Sottocornola M, Kiely G. How strong is the current carbon sequestration of an Atlantic blanket bog? Global Chang Biol. 2011;17:309-19. doi:10.1111/j.1365-2486.2010.02180.x.

66. Reed MS, Allen K, Attlee A, Dougill AJ, Evans KL, Kenter JO, et al. A placebased approach to payments for ecosystem services. Global Environ Chang. 2017:43:92-106. doi:10.1016/j.gloenvcha.2016.12.009.

67. Wilson D, Renou-Wilson F, Farrell C, Bullock C, Müller C. Carbon restorethe potential of restored Irish peatlands for carbon uptake and storage. Johnstown Castle: Environmental Protection Agency; 2012.

68. Wilson D, Dixon SD, Artz RRE, Smith TEL, Evans CD, Owen HJF, et al. Derivation of Greenhouse Gas emission factors for peatlands managed for extraction in the Republic of Ireland and the United Kingdom. Biogeosci Discuss. 2015;12:7491-535.

69. Bonn A, Reed MS, Evans CD, Joosten H, Bain C, Farmer J, et al. Investing in nature: developing ecosystem service markets for peatland restoration. Ecosyst Serv. 2014;9:54-65. doi:10.1016/j.ecoser.2014.06.011.

70. IPCC. 2013 supplement to the 2006 IPCC guidelines for National Greenhouse Gas Inventories: Wetlands. Geneva: IPCC; 2014.

71. Wilson D, Farrell CA, Fallon D, Moser G, Müller C, Renou-Wilson F. Multiyear greenhouse gas balances at a rewetted temperate peatland. Glob Change Biol. 2016;22:4080-95. doi:10.1111/gcb.13325.

72. Bullock CH, Collier MJ, Convery F. Peatlands, their economic value and priorities for their future management- the example of Ireland. Land Use Policy. 2012;29:921-8. doi:10.1016/j.landusepol.2012.01.010.
73. Bord na Móna. Bord na Móna Raised Bog Restoration Project. 2016.

74. Grand-Clement E, Anderson K, Smith D, Angus M, Luscombe DJ, Gatis N, et al. New approaches to the restoration of shallow marginal peatlands. J Environ Manag. 2015;161:417-30. doi:10.1016/j.jenvman.2015.06.023.

75. Landis JR, Koch GG. The measurement of observer agreement for categorical data. Biometrics. 1977;33:159-74. doi:10.2307/2529310.

76. Lathrop S, Stow D, Coulter L, Hope A. Delineating new foot trails within the US-Mexico border zone using semiautomatic linear object extraction methods and very high resolut. J Spat Sci. 2010;55:84-100.

77. Hammond TO, Verbyla DL. Optimistic bias in classification accuracy assessment. Int J Remote Sens. 1996;17:1261-6. doi:10.1080/01431169608949085.

78. Schöpfer E, Lang S. Object fate analysis — a virtual overlay method for the categorisation of object transition and object-based accuracy assessment. In: Proceedings of 1st international conference on object based image analysis (OBIA 2006). Salzburg; 2006.

79. European Commission. Second Biennial Report of the European Union under the UN Framework Convention on Climate Change. Brussels; 2015.

80. Joosten H, Tapio-Biström M-L, Tol S. Peatlands — guidance for climate change mitigation through conservation, rehabilitation and sustainable use, 2nd edn. UN FAO and Wetlands International; 2012.

81. European Commission. Mapping and assessment of ecosystems and their services: mapping and assessing the condition of Europe's ecosystems: Progress and challenges; 2016.

82. Smyth MA, Taylor ES, Birnie RV, Artz RRE, Dickie I, Evans C, et al. Developing peatland carbon metrics and financial modelling to inform the pilot phase UK peatland code. Dumfries: Crichton Carbon Centre; 2015.

83. Grand-Clement E, Anderson K, Smith D, Luscombe D, Gatis N, Ross M, et al. Evaluating ecosystem goods and services after restoration of marginal upland peatlands in South-West England. J Appl Ecol. 2013;50:32434. doi:10.1111/1365-2664.12039.

84. Dirks BOM, Hensen A, Goudriaan J. Effect of drainage on $\mathrm{CO} 2$ exchange patterns in an intensively managed peat pasture. Clim Res. 2000;14:57-63.

85. O'Connell J, Connolly J, Holden NM. A monitoring protocol for vegetation change on Irish peatland and heath. Int J Appl Earth Obs Geoinform. 2014;31:130-42.

86. Copernicus. Sentinels 2016. http://www.copernicus.eu/main/sentinels. Accessed 20 Feb 2017).

\section{Submit your manuscript to a SpringerOpen ${ }^{\circ}$ journal and benefit from:}

- Convenient online submission

- Rigorous peer review

- Immediate publication on acceptance

- Open access: articles freely available online

- High visibility within the field

- Retaining the copyright to your article

Submit your next manuscript at $\boldsymbol{\nabla}$ springeropen.com 